Thirdly, the state recognizes that the actual size of the living wage is almost 2 times higher than the amount determined by the Law of Ukraine "On the State Budget of Ukraine for 2020" as a subsistence minimum.

As a result, the living wage, as an image, has no relation to reality and this fact is not hidden, which corresponds to the fourth phase of the image's existence (the phase of a pure simulacrum).

And this simulacrum forms a new unreal reality - hyperreality.

As a basic state social standard, the cost of living affects the size of wages, pensions, social benefits, single tax, fines, benefits. It is also important for the qualification of administrative and criminal offenses.

Thus, the real amounts (the amounts that we pay or receive) of wages, taxes, fines, etc. calculated on the basis of the living wage category, which is not filled with real content.

Do categories based on something unreal become real? Are the indicators calculated on the basis of an unrealistic living wage consistent with reality? Do not match! Can the amount of wages, pensions, unemployment benefits, social benefits be considered real? No! But we have no other legal and social reality than one built on an unrealistic living wage.

The living wage, in a certain sense, is the duty of the social state, and the attribution of the living wage to the sphere of the hyperreal, raises doubts about the reality of the state's fulfillment of the obligations that it imposes on itself in the Constitution of Ukraine.

Keywords: simulacrum, legal simulacrum, living wage, state social standards, welfare state.

DOI: 10.33766/2524-0323.91.348-355

УДК 614.46:378:351.74(477)

М. Ф. Недоступ, кандидат медичних наук, доцент, доцент кафедри спеціальних дисциплін та домедичної підготовки

Луганського державного університету внутрішніх справ імені Е. О. Дідоренка (м. Сєвєродонецьк, Україна) e-mail: nednik95@gmail.com iD https://orcid.org/0000-0001-6380-0409

\title{
ДОМЕДИЧНА ПІДГОТОВКА КУРСАНТІВ ЛУГАНСЬКОГО ДЕРЖАВНОГО УНІВЕРСИТЕТУ ВНУТРІШНІХ СПРАВ IМЕНІ Е. О. ДІДОРЕНКА В УМОВАХ КАРАНТИНУ
}

У статті розглянуто питання щодо домедичної підготовки курсантів Луганського державного університету внутрішніх справ в умовах карантину, а також проблеми використання виключно дистанщійної форми навчання. Проведено аналіз особливостей навчання курсантів при вивченні домедичної підготовки під час карантину з використанням платформ Moodle, Microsoft Teams, поштового клієнта Outlook. Зауважено, що дистанщійне навчання може бути ефективною формою засвоення знань із домедичної підготовки, у разі якщо практично оволодіти певними вміннями та навичками для своєчасного та ефективного надання допомоги. Однак зазначено, що його можна застосовувати як вимушений захід, і лише в екстремальних ситуаціях, як, наприклад, чітко не визначений у часі карантин під час пандеміі. У разі тривалого застосування такий вид навчання може призвести до зниження навчальної мотивації та неякісної підготовки курсантів. 
Одночасно, набутий досвід може стати суттєвою підмогою курсантам при підготовці до занять із домедичної підготовки.

Ключові слова: домедична підготовка, навички, дистанщійна освіта, карантин, правоохоронні органи.

Постановка проблеми. На сьогодні проблема надання домедичної допомоги залишається надзвичайно актуальною. Ії нагальність набуває найбільшого значення в умовах пандемії коронавірусу. Травмування, серцевий напад, утрата свідомості як реагувати на ці ситуації, щоб врятувати життя людини, поки швидка ӥде за викликом? Це в повній мірі стосується і працівників Національної поліції [8], адже ніхто не знає, з чим прийдеться стикнутися завтра за будь-яких обставин. Суттєво вплинути на таку ситуацію неможливо, тому єдине, що залишається, - це засвоєння методик своєчасної та ранньої невідкладної допомоги.

Негайне надання першої допомоги особливо необхідно в станах, які гостро розвиваються, загрожують життю і здоров'ю людини, а також у надзвичайних ситуаціях і при нещасних випадках. Від правильно наданої першої допомоги нерідко залежить успіх подальшої медичної кваліфікованої допомоги. Наприклад, швидке і правильне накладання пов'язки й шини при відкритому переломі кістки нерідко запобігає небезпечним ускладненням (шок, інфекція та ін.) або врахування положення хворого в несвідомому стані з поверненою убік головою перешкоджає потраплянню блювотних мас і крові у дихальні шляхи й настанню смерті в найближчі хвилини від асфіксії.

На сьогодні вимоги та порядок надання домедичної допомоги при невідкладних станах викладено в наказі Міністерства охорони здоров'я України від 16.06.2014 № 398 «Про затвердження порядків надання домедичної допомоги особам при невідкладних станах» [9]. Навчання осіб, що не мають медичної освіти, останнім часом було стандартизовано й почало здійснюватися системно та за різними програмами згідно з наказом МОЗ України від 29.03.2017 р. № 346 «Про удосконалення підготовки з надання домедичної допомоги осіб, які не мають медичної освіти» [10].

Якість надання домедичної допомоги в екстремальних умовах залежить у першу чергу від власної безпеки (фізичний, біологічний та інші аспекти), досконалого визначення стану постраждалого, характеру отриманих поранень, рівня знань і навичок рятівника, який контактує з пораненим та наявного медичного обладнання. Важкі травми та поранення зумовлють виникнення невідкладних станів, які спричиняють смерть. Найчастіше до причин, які призводять до незворотніх наслідків, відносять масивну кровотечу, гостру дихальну недостатність та невідкладні серцевосудинні стани [5].

Безперечно, знання та навички стануть у нагоді кожному з курсантів у багатьох різноманітних ситуаціях. Саме завдяки застосуванню простих прийомів кожен із них зможе врятувати життя потерпілим, зменшити їхнє страждання, запобігти можливим ускладненням, допомогти при травмах під час несення служби, активного відпочинку або в ситуації стихійного лиха тощо.

Аналіз останніх досліджень і публікацій. Аналіз джерел із зазначеної вище проблеми свідчить про значний інтерес багатьох науковців до питань розвитку сучасної освіти (В. Ю. Биков, В. М. Кухаренко, І. В. Грушина, С. В. Долинський, С. С. Полат та ін.) $[1 ; 2 ; 3 ; 7 ; 11]$. Тенденції впровадження сучасних інформаційних 
технологій у процес навчання показує, що в даний час у багатьох розвинутих країнах відбувається процес кардинальних змін у системі освіти. Одним із провідних завдань, яке стоїть перед викладачами ЗВО, є не тільки впровадження системи дистанщійної освіти, а й забезпечення сприятливого впливу нових технологій на освітній процес, тобто необхідність розвитку сильних сторін і мінімізація негативних [6; 12].

Формулювання цілей. Під час карантину, зумовленого пандемією коронавіpусу COVID-19, чи не єдиним можливим варіантом здобуття знань стає дистанщійне навчання, що забезпечує курсантів основним обсягом навчального матеріалу, демонструє інтерактивну взаємодію курсантів і викладачів у процесі навчання, надає курсантам можливості самостійної роботи з навчальними матеріалами.

Оскільки тривалість карантину не може бути прогнозованою, білышого значення набуває ідея посилення самостійності при навчанні курсантів, коли взаємодія викладача й курсанта відбувається у віртуальному просторі: усі перебувають за своїми комп'ютерами й спілкуються за допомогою інтернету.

Поширення COVID-19 спонукало до термінового перегляду можливостей дистанщійних технологій навчання та сприяло їх впровадженню як основних навчальних технологій для забезпечення безперервності навчального процесу в умовах надзвичайного стану [4]. Не став винятком Луганський державний університет внутрішніх справ опіків та відповідно наданої допомоги. При проведенні практичних занять використовуються різні навчальні засоби (повітроводи для деобструкції дихальних шляхів, сучасні кровоспинні засобі, джгути-турнікети, транспортні шини Крамера і Дітеріхса тощо). Крім того, курсанти із задоволенням відпрацьовують методику серцево-легеневої реанімації з акцентом на особливостях виконання зовнішнього масажу серця та штучної вентилящії легень у дорослих та дітей на тренажері серцево-легеневої реанімації з індикацією правильності виконання дій. Треба зазначити, що використання симуляторів дає можливість курсанту освоїти необхідні навички, навчитися працювати відповідно до сучасних алгоритмів надання допомоги, підвищити рівень виконання маніпуляцій й оцінити ефективність власних дій, що дозволить у подальшому уникати помилок у реальних умовах.

Для оцінки сформованості практичних навичок ми використовуємо рольові ігри та розв'язуємо ситуаційні завдання з аргументацією послідовності виконання своїх дій й аналізом ефективності їх застосування в залежності від умов, визначених у них. Так у ході рольової гри курсант опиняється в ситуації, яка являє собою моделювання алгоритму дій у тих самих умовах, які існують у реальному житті за певний час і які дають можливість перевірити достатність підготовки.

Однак повний перехід на дистанщійне навчання висвітлив деякі особливості при вивченні домедичної підготовки. Відразу треба зазначити, що термінове впровадження дистанщійного навчання не стало чимось надзвичайним, тому що елементи дистанщійного навчання активно застосовувалися протягом останніх років в університеті. Проте довелося докласти чимало зусиль для термінового доповнення занять інформаційним контентом, навчальним відеоматеріалом, задачамий тестами. Знадобився також додатковий час для підвищення рівня комп' ютерної освіти.

Під час навчання курсантами домедичної підготовки за дистанційною формою ми використовували платформи Moodle та Microsoft Teams. Зокрема, платформа Youtube застосовувалась для завантаження лекцій, розгляду прикладів окремих 
травм тощо. Оперативний зв'язок та координація дій із курсантами здійснювалися через сервіс Outlook.

Загалом поєднання можливостей кожного сервісу дозволяє успішно в режимі реального часу проводити дистанщійне навчання, надавати курсантам інформаційну підтримку, контролювати виконання завдань, роботу з тестами, коментувати відповіді та направляти їхні дії.

Водночас застосування цілковито дистанщійних занять виявило ряд взаємопов'язаних проблем. На процес проведення занять впливав звичний стиль викладання педагогічного працівника, який став уже не можливий у нових умовах, а також певний рівень володіння ним комп' ютером. Крім того, треба розуміти, що студенти теж опинилися в незвичних умовах і їм необхідно було докласти немало зусиль, щоб пристосуватися до нових вимог організації навчального процесу.

Платформа Moodle вже тривалий час досить ефективно використовується для розміщення навчально-методичного матеріалу, проходження курсантами тестування з відповідних тематичних та модульних занять та розв'язання ситуаційних завдань. Треба визнати, що застосування тестових завдань зменшує дефіцит часу та досить швидко визначає певний мінімум необхідних знань курсанта, проте ми не імені Е. О. Дідоренка.

Тож метою статті є визначення основних проблем, що виникають при дистанщійному вивченні домедичної підготовки курсантами Луганського державного університету внутрішніх справ імені Е. О. Дідоренка, розгляд можливостей їх запобігання та розв'язання складних ситуацій.

Виклад основного матеріалу. В основі підготовки з надання домедичної допомоги лежить засвоєння практичних навичок. Уміння і навички надання першої допомоги формуються після багаторазового повторення й доведення до автоматизму при суворому дотриманні послідовності їх виконання. Через те на практичних заняттях ми використовуємо тренажерне обладнання, що дозволяє максимально ефективно освоювати матеріал й удосконалювати навички надання допомоги в ряді екстрених і невідкладних станів: при артеріальній кровотечі, при зупинщі дихання та серцевої діяльності, при травматичних ушкодженнях і пораненнях, опіках і відмороженнях, отруєннях. За багаторічний досвід навчання практичним навичкам на різних типах тренажерів ми переконалися, що використання якісних навчальних манекенів $є$ необхідною умовою набуття навичок із надання домедичної допомоги, тому що вони дозволяють значно підвищити засвоюваність матеріалу. Крім того, моделювання ситуацій з імітацією поранень, травм і штучною кров'ю зумовлює орієнтацію на необхідність використання курсантами індивідуальних засобів захисту, наприклад, рукавичок тощо.

Переважна більшість занять із домедичної підготовки відбуваються у формі тренінгу, під час яких курсанти охоче вчаться на манекенах, як правильно оцінювати стан потерпілого, забезпечувати прохідність дихальних шляхів, використовуючи прийом Сафара, визначати стан свідомості та виявляти ознаки життя постраждалої людини. Курсанти відпрацьовують практичні навички накладання джгутівтурнікетів для зупинки кровотечі, транспортних шин при переломах і пов' язок при пораненнях різних ділянок тіла.

Завдяки своєчасно придбаному навчальному оснащенню, значну зацікавленість у курсантів викликали імітатори травм, кровотеч, поранень м'яких тканин, 
можемо відмовитися від ситуаційних завдань, які потребують логічних висновків та застосування медичних знань.

Для організації відеозустрічей із курсантами дуже дієвим виявився сервіс Мicrosoft Teams, який надає доступ до спілкування для всієї аудиторії. Викладач має можливість відповісти в зручний для себе час. До того ж діалог зберігається, у разі необхідності його можна переглянути будь-коли. Ще одним зручним елементом дистанщійного навчання є використання сервісу Outlook для відповідей на питання студентів та письмових консультацій.

Раптове введення карантину сприяло створенню відеоконтенту з демонстрацією надання домедичної допомоги при різних невідкладних станах.

Такий підхід дозволяє курсанту наочно визначати послідовність дій при наданні допомоги й повторно переглянути навчальний матеріал з метою закріплення отриманої інформації.

Для дистанщійної імітації практичних навичок ми застосовуємо, крім відео, також презентації. Їх перевагою є те, що курсант отримує ще й додаткові матеріали у вигляді алгоритму дій, практичних порад при наданні першої допомоги, інструкщій, пояснень тощо. На нашу думку, при розгляді анатомо-фізиологічних особливостей будови окремих систем організму людини,доречним кроком виглядає використання в майбутньому 3D-презентаційних моделей, що забезпечувало б ще більш високу якість наочності.

Проте, маємо й негативні сторони застосування дистанщійного навчання. Одна 3 проблем - пошук та використання курсантами необхідної інформації в мережі Інтернет з подальшим обміном відповідей між собою. Так при проведенні занять були випадки, коли дехто з курсантів мали абсолютно однакові відповіді. На це вказували деякі неточності, які регулярно повторювалися в загалом правильних відповідях. Тому одним з шляхів виходу з цієї ситуації, на наш погляд, $є$ посилення вимог до опанування курсантами білыш вичерпної за обсягом інформації. Це виглядає цілком виправданим, тому що пошук інформації для розв'язання складного питання залишає відбитки в пам'яті курсанта та може стати йому в нагоді в майбутньому.

Крім того, проведення занять у виключно дистанщійній формі продемонструвало, що через збільшене навантаження деякі online-сервіси можуть працювати менш стабільно, ніж звичайно.

Висновки. Отже, практика викладання домедичної підготовки курсантам Луганського державного університету внутрішніх справ імені Е. О. Дідоренка в умовах карантину продемонструвала, що дистанційне навчання може бути ефективною формою засвоення знань із домедичної підготовки. Водночас, домедична підготовка - це прикладна дисципліна, яка потребує оволодіння певними вміннями та навичками для своєчасного та ефективного надання допомоги, тому дистанщійне навчання даної дисципліни не може повною мірою замінити ії вивчення без відпрацювання практичних умінь та навичок. Винятково дистанщійне навчання, як вимушений захід, може впроваджуватися лише в надзвичайних ситуаціях. У разі тривалого застосування такий вид навчання може призвести до зниження навчальної мотиващії та якісної підготовки курсантів. Одночасно, набутий досвід може стати суттєвою підмогою курсантам при підготовці до занять із домедичної підготовки. 


\section{Використані джерела:}

1. Биков В. Ю. Дистанційне навчання в країнах Європи та США і перспективи для України/В. Ю. Биков// Інформаційне забезпечення навчально--иховного процесу: інноваційні засоби і технологіӥ: кол. монографія/В. Ю. Биков, О. О. Гриценчук, Ю. О. Жук та ін./ Академія педагогічних наук України, Інститут засобів навчання. Київ: Атіка, 2015. C. 77-214фушина I. В. Теоретичні та методологічні основи використання дистанщійних технологій в контексті змішаного навчання/І. В. Грушина //Наукові записки. Серія: Проблеми методики фрізико-математичної і технологічної освіти. Вип. 10 (1). Кіровоград: РВВ КДПУ ім. В. Вінниченка, 2016. С. 28-34.

3. Долинський Є. В. Дистанщійне навчання - одна з прогресивних форм підготовки фахівців / Є. В. Долинський/ / Теоретичні питання культури, освіти та виховання: Збірникнаукових праць. Вип. 42 /За заг. ред. проф. Матвієнко О. В. К.: Вид. центр КНЛУ, 2010. С. 202-207.

4. Дистанційне навчання як сучасна освітня технологія [Електронний ресурс]: мaтеріали міжвузівського вебінару (м. Вінниця, 31 березня 2017 р.) / відп. ред. Л. Б. Ліщинська. Віннищя: ВTEI KHTEУ, 2017. 102 с.

5. Домедична підготовка: підручник / [А. В. Самодін, О. В. Чуприна, Т. П. Жилін та ін.]; за заг. ред. В. В. Стеблюка. Харків: Право, 2020. 344 с.

6. Осадчий В. В. Сучасні тенденщії використання інформаційниї технологій у навчальному процесі вищої педагогічної школи / В. В. Осадчий/ / Педагогічний процес: теорія $і$ практика. Збірник наук. праць. К.: Видавництво П/П «ЕКМО», 2009. Вип. 2. С. 190-207.

7. Полат Е. С. Дистанционное обучение: учеб. пособие/под ред. Е. С.Полат. М.: Гуманит. изд. Центр ВЛАДОС, 1998. 192 с.

8. Про Національну поліцію [Електронний ресурс]: Закон України від 2 лип. 2015 p. № 580-VIII. Режим доступу: http:/ / zakon3.rada. gov.ua/laws/show/580-19.

9. Прозатвердження порядків надання домедичної допомоги особам при невідкладних станах [Електронний ресурс]: наказ Міністерства охорони здоров'я України від 16 черв. 2014 р. № 398. Режим доступу:https:/ /zakon.rada.gov.ua/laws/show/z0750-14\#Text.

10. Про удосконалення підготовки з надання домедичної допомоги осіб, які не мають медичної освіти [Електронний ресурс]: наказ Міністерства охорони здоров'я України від 29 берез. 2017 p. № 346. - Режим доступу: search.ligazakon.ua/__doc2.nsf/link1/MOZ27273.html.

11. Розробки дистанщійного курсу: Навчальний посібник / За ред. В. Ю. Бикова та В. М. Кухаренка. Київ: Міленіум, 2008. 324 с.

12. ШиндерО. В. Дистанщійна освіта як фактор підвищення конкурентоспроможності вищих навчальних закладів / О. В. Шиндер/ / Якість вищої освіти: чинники формубання конкурентоспроможності випускників: Матеріали ХXXIX Міжнар. наук.-метод. конф., (м. Полтава, 2324 січня 2014 р.). Полтава: ПУЕТ, 2014. С. 172-174.

\section{References:}

1. Bykov, V. Yu. (2015) Dystantsiine navchannia v krainakh Yevropy ta SShA i perspektyvy dlia Ukrainy. Informatsiine zabezpechennia navchalno-vykhovnoho protsesu: innovatsiini zasoby $i$ tekhnolohii: kol. Monohrafiia- Information support of the educational process: innovative tools and technologies: col. Monograph. V. Yu. Bykov, O. O. Hrytsenchuk, Yu. O. Zhuk (Eds.) et al. Akademiia pedahohichnykh nauk Ukrainy, Instytut zasobiv navchannia. Kyiv: Atika, 77-140. [in Ukrainian].

2. Hrushyna, I. V. (2016) Teoretychni ta metodolohichni osnovy vykorystannia dystantsiinykh tekhnolohii v konteksti zmishanoho navchannia. Naukovi zapysky. Seriia: Problemy metodyky fizyko-matematychnoi i tekhnolohichnoi osvity - Proceedings. Series: Problems of methods of physical-mathematical and technological education. Kirovohrad: RVV KDPU im. V. Vinnychenka, issue10(1), 2834. [in Ukrainian].

3. Dolynskyi, Ye. V. (2010) Dystantsiine navchannia - odna z prohresyvnykh form pidhotovky fakhivtsiv. Matviienko, O. V. (Ed.) Teoretychni pytannia kultury, osvity ta vykhovannia: 
Zbirnyk naukooykh prats- Theoretical issues of culture, education and upbringing: Collection of scientific works, issue 42, 202-207. Kyiv: Vyd. tsentr KNLU. [ in Ukrainian].

4. Lishchynska, L. B. (Ed.). (2017). Dystantsiine navchannia yak suchasna osvitnia tekhnolohiia: materialy mizhouzivskoho vebinaru ( $m$. Vinnytsia, 31 bereznia 2017 r.) - Distance learning as a modern educational technology: materials of the interuniversity webinar (Vinnytsia, March 31, 2017). Vinnytsia: VTEI KNTEU. [in Ukrainian].

5. Domedychna pidhotovka: pidruchnyk. (2020) A. V. Samodin, O. V. Chupryna, T. P. Zhylin (Eds.) et al.; V. V. Stebliuk (Ed.). Kharkiv: Pravo. [in Ukrainian].

6. Osadchyi, V. V. (2009) Suchasni tendentsii vykorystannia informatsiinyi tekhnolohii u navchalnomu protsesi vyshchoi pedahohichnoi shkoly. Pedahohichnyi protses: teoriia i praktyka. Zbirnyk nauk. prats. - Pedagogical process: theory and practice. Collection of sciences. wash. Kyiv: Vydavnytstvo P/P «EKMO», issue 2, 190-207. [in Ukrainian].

7. Polat, E. S. (1998) Dystantsyonnoe obuchenye: ucheb. Posobye. E. S. Polat (Ed.). Moskva: Humanyt. yzd. Tsentr VLADOS. [in Russian].

8. Pro Natsionalnu politsiiu: Zakon Ukrainy vid 2 lyp. 2015 r. № 580-VIII. (2015) N. p. URL:http://zakon3.rada.gov.ua/laws/show/580-19. [in Ukrainian].

9. Pro zatverdzhennia poriadkiv nadannia domedychnoi dopomohy osobam pry nevidkladnykh stanakh: nakaz Ministerstva okhorony zdorov' ia Ukrainy vid 16 cherv. 2014 r. № 398. (2014) N. p. URL:https://zakon.rada.gov.ua/laws/show/z0750-14\#Text. [in Ukrainian].

10. Pro udoskonalennia pidhotovky $\mathrm{z}$ nadannia domedychnoi dopomohy osib, yaki ne maiut medychnoi osvity: nakaz Ministerstva okhorony zdorov'ia Ukrainy vid 29 berez. 2017 r. № 346. (2017) N. p. URL: search.ligazakon.ua/ldoc2.nsf/link1/MOZ27273.html. [in Ukrainian].

11. Rozrobky dystantsiinoho kursu: Navchalnyi posibnyk. (2008). V. Yu. Bykov, \& V. M. Kukharenko (Eds.). Kyiv: Milenium. [in Ukrainian].

12. Shynder, O. V. (2014) Dystantsiina osvita yak faktor pidvyshchennia konkurentospromozhnosti vyshchykh navchalnykh zakladiv. Yakist vyshchoi osvity: chynnyky formuvannia konkurentospromozhnosti vypusknykiv: materialy KhKhXIX Mizhnar. nauk.-metod. konf., (m. Poltava, 23-24 sichnia 2014 r.) - Quality of higher education: factors shaping the competitiveness of graduates: Materials XXXXX International. scientific method Conf. (Poltava, January 23-24, 2014). Poltava: PUET, 172-174. [in Ukrainian].

Стаття надійшиа до редколегії 29.08.2020

Недоступ Н. Ф.,

кандидат медицинских наук, доцент, доцент кафедры специальных дисциплин и домедицинской подготовки Луганского государственного университета внутренних дел имени Э. А. Дидоренко (г. Северодонецк, Украина)

\section{ДОМЕДИЦИНСКАЯ ПОДГОТОВКА КУРСАНТОВ ЛУГАНСКОГО ГОСУДАРСТВЕННОГО УНИВЕРСИТЕТА ВНУТРЕННИХ ДЕЛ ИМЕНИ Э. А. ДИДОРЕКО В УСЛОВИЯХ КАРАНТИНА}

В статье рассмотрены вопросы домедицинской подготовки курсантов Луганского государственного университета внутренних дел имени Э. А. Дидоренко в условиях карантина, а также проблемы использования исключительно дистанщионной формы обу- 
чения. Проведен анализ особенностей обучения курсантов при изучении домедицинской подготовки во время карантина с использованием платформ Moodle, Microsoft Teams, почтового клиента Outlook. Замечено, что дистанционное обучение может быть эффективной формой усвоения знаний по домедицинской подготовке, если практически овладеть определенными умениями и навыками для своевременного и эффективного оказания помощи. Однако отмечено, что его можно применять как вынужденнаю меру, и только в экстремальных ситуациях, например, в случае длительного карантина во время пандемии. В случае длительного применения такой вид обучения может привести кснижению учебной мотивации и некачественной подготовки курсантов. Одновременно приобретенный опыт может стать существенным подспорьем курсантам при подготовке к занятиям по домедицинской подготовке.

Ключевые слова: домедищинская подготовка, навыки, дистанционное образование, карантин, правоохранительные органы.

Nedostup M., Candidate of Medical Sciences, Associate Professor, Associate Professor of the Department of Special Disciplines and Pre-Medical Training of Luhansk State University of Internal Affairs named after E. Didorenko (Sievierodonetsk, Ukraine)

\section{PRE-MEDICAL TRAINING OF TRAINERS OF LUGANSK STATE UNIVERSITY OF INTERNAL AFFAIRS NAMED AFTER E. DIDORENKO UNDER QUARANTINE}

The article deals with the issues of pre-medical training of cadets of the Lugansk State University of Internal Affairs named after E. Didorenko in quarantine conditions, as well as the problems of using exclusively distance learning. The use of modern Internet technologies has provided support for effective training in extreme quarantine conditions. The analysis of features of training of cadets at studying of pre-medical preparation during quarantine with use of platforms Moodle, Microsoft Teams, the Outlook e-mail client is carried out. Some problems of using only distance learning are considered.

The practice of teaching pre-medical training in quarantine has shown that distance learning can be an effective form of acquiring knowledge of pre-medical training. At the same time, home medical training is an applied discipline that requires the acquisition of certain skills and abilities to provide timely and effective care. Therefore, distance learning of this discipline can not fully replace its study without practicing practical skills and abilities. Only distance learning, as a compulsory measure, can be used only in extreme conditions. In the case of long-term use, this type of training can reduce the learning motivation of cadets and the quality of their training. At the same time, the gained experience can be a significant help to cadets in preparation for home medical training.

The article discusses the issues of pre-medical training in quarantine conditions, as well as the problems of using exclusively distance learning. It is noticed that distance learning can be an effective form of assimilation of knowledge on pre-medical training, if you practically master certain skills for timely and effective assistance. However, it was noted that it can be used as a forced measure, and only in extreme situations, for example, in the case of prolonged quarantine during a pandemic. In the case of long-term use, this type of training can lead to a decrease in educational motivation and poor-quality training of cadets. At the same time, the experience gained can become a significant help to cadets in preparation for pre-medical training classes. 